\title{
Efektivitas Program Badan Penyelenggara Jaminan Sosial (BPJS) Dalam Pelayanan Kesehatan Di Puskesmas Wajo Kota Baubau
}

\author{
Witri Wulandari \\ Guru SMA Negeri 2 Baubau, \\ Dosen Universitas Muhammadiyah Buton
}

\begin{abstract}
ABSTRAK
Salah satu bentuk pelayanan kesehatan yang dapat memberikan keringanan bagi masyarakat adalah Program Badan Penyelenggaraan Sosial (BPJS) Kesehatan yang baru diluncurkan pada Januari 2014. Penelitian ini bertujuan untuk mengkaji efektivitas pelaksanaan program BPJS dengan focus studi pada Puskesmas Wajo Kota Baubau.

Program BPJS Kesehatan ini dapat diperoleh di Kantor BPJS Kesehatan di Kabupaten/Kota setempat sesuai dengan domisili dari peserta. Sehingga apabila pasien/peserta BPJS Kesehatan ingin berobat di Puskesmas atau Rumah Sakit yang menggunakan pelayanan kesehatan dengan kartu BPJS Kesehatan, maka peserta/pasien BPJS Kesehatan dapat berobat secara gratis dengan menunjukkan karti BPJS Kesehatan yang sudah dimiliki oleh peserta.
\end{abstract}

Kata Kunci : Efektivitas, BPJS, Pelayanan Kesehatan 


\section{A. PENDAHULUAN}

Masyarakat sehat yang mandiri dan berkeadilan" adalah merupakan visi dari Kementerian Kesehatan dalam melaksanakan pembangunan kesehatan. Dalam upaya menuju masyarakat sehat yang mandiri dan berkeadilan, maka pembangunan pelayanan kesehatan di Indonesia mulai beralih dan berorientasi kepada Paradigma Sehat. Ini berarti seluruh kegiatan pelayanan kuratif dan rehabilitatif harus mempunyai daya ungkit yang tinggi bagi peningkatan kesehatan dan pencegahan penyakit orang sehat.

Salah satu tujuan dari pembangunan kesehatan di Indonesia adalah upaya untuk memperbaiki kualitas pelayanan kesehatan. Pelayanan yang berkualitas ini harus dapat dilaksanakan di seluruh sarana pelayanan kesehatan pemerintah maupun swasta. Dengan pelayanan kesehatan yang bermutu ini diharapkan masyarakat akan lebih berminat untuk memanfaatkan sarana pelayanan kesehatan mulai dari tingkat puskesmas, rumah sakit dan sarana pelayanan kesehatan lain.

Kesehatan bukan semata-mata merupakan tanggung jawab dari Kementerian Kesehatan, melainkan juga tanggung jawab dari seluruh sektor, termasuk masyarakat dan swasta. Salah satu bentuk pelayanan kesehatan yang dapat memberikan keringanan bagi masyarakat melalui Program Badan Penyelenggara Jaminan Sosial (BPJS) Kesehatan.

BPJS Kesehatan ini dapat diperoleh di Kantor Askes Kabupaten/Kota setempat sesuai domisili dari peserta BPJS. Sehingga apabila pasien/peserta BPJS ingin berobat di Puskesmas atau Rumah Sakit yang menggunakan pelayanan kesehatan dengan kartu BPJS maka peserta/pasien BPJS dapat berobat secara gratis dengan menunjukkan Kartu BPJS yang sudah dimiliki oleh peserta.

Program BPJS Kesehatan baru diberlakukan pada bulan Januari 2014. Prgram ini dilaksanakan oleh PT Askes. Kesiapan PT Askes sebagai BPJS Kesehatan telah melakukan berbagai persiapan menuju BPJS Kesehatan sesuai dengan amanat Undang-Undang BPJS untuk mengelola jaminan kesehatan.

Selama ini. Puskesmas Wajo sebagai salah satu Puskesmas yang melayani masyarakat dalam hal pelayanan kesehatan di Kota Baubau telah memberikan oelayanan kesehatan dengan sangat optimal. Dengan diberlakukannya Program BPJS Kesehatan oleh pemerintah maka Puskesmas Wajo juga harus melakukan penyesuaian dengan program yang baru diberlakukan.

Berdasarkan uraian di atas penelitian ini berusaha melakukan pengkajian terhadap Efektivitas Program BPJS Kesehatan dalam Pelayanan Kesehatan di Kota Baubau, dengan mengambil Studi pada Puskesmas Wajo Kota Baubau.

\section{B. Metode Penelitian}

Jenis penelitian yang digunakan penulis dalam penelitian ini adalah metode deskriptif dengan pendekatan kualitatif. Sebagaimana dikatakan Nawawi (2009: 64) bahwa metode deskriptif memusatkan perhatian terhadap masalah-msalah atau fenomena yang ada pada saat penelitian dilakukan atau bersifat aktual, kemudian menggambarkan fakta-fakta tentang masalah yang diselidiki sebagaimana 
adanya diiringi dengan interpretasi rasional yang akurat.

Populasi dari penelitian ini adalah pasien pengguna kartu BPJS Kesehatan di Puskesmas Wajo Kota Baubau yang berjumlah 600 pasien.

Sampel dalam penelitian ini diambil berdasarkan 10\% dari 600 pasien BPJS Kesehatan sehingga didapatlan 60 responden dari pasien BPJS Kesehatan. Sedangkan dari pihak Puskesmas Wajo (Dokter, perawat bagian kartu, bagian pengobatan, dan tenaga para medis) penulis mengambil hanya 5 orang responden. Di dapat seluruh sampel berjumlah 65 orang responden.

Teknik analisa data yang digunakan Menurut Farid (2009:152) bahwa analisa kualitatif adalah analisa terhadap data yang diperoleh berdasarkan kemampuan nalar peneliti dalam menghubung-hubungkan fakta dan informasi, data dan informasi. dengan cara menjabarkan hasil penelitian sebagaimana adanya. Data yang didapat akan dipaparkan dan dianalisa dengan menggunakan tabel tunggal.

\section{Hasil Penelitian dan Pembahasan}

Sejak tanggal 1 januari 2014, PT Askes Indonesia (Persero) berubah nama menjadi BPJS Kesehatan sesuai dengan Undang-Undang Nomor 24 Tahun 2011 tentang BPJS. BPJS Kesehatan (Badan Penyelenggara Jaminan Sosial Kesehatan) merupakan Badan Usaha Milik Negara yang ditugaskan khusus oleh pemerintah untuk menyelenggarakan jaminan pemeliharaan kesehatan bagi seluruh rakyat Indonesia, terutama untuk Pegawai Negeri Sipil, Penerima PensiunanPNS dan TNI/Polri, Veteran,
Perintis Kemerdekaan beserta keluargnya dan Badan Usaha Lainnya ataupun rakyat biasa.

Penelitian ini dilakukan terhadap pasien pengguna kartu BPJS Kesehatan dan pegawai Puskesmas Wajo dimana sampel yang telah ditentukanadalah 60 orang pasien pengguna kartu BPJS Kesehatan, dan 5 orang dari petugas Puskesmas Wajo (dokter, pegawai kartu, asisten apoteker).

\section{1) Kondisi Pelayanan BPJS Kesehatan.}

Adapun pengukuran efektivitas pelayanan BPJS dilakukan melalui indikator sebagai berikut :

\section{a. Proses Pelayanan}

Dalam pelaksanaan Pelayanan Pasien Pengguna BPJS Kesehatan, pegawai Puskesmas tentu menjadi factor penentu dalam pelayanannya. Mengenai hal ini didapati tanggapan sebagai berikut.

Tabel 1

Tanggapan Tentang Proses Pelayanan

\begin{tabular}{|c|l|c|c|}
\hline No & $\begin{array}{l}\text { Tanggapan } \\
\text { Responden }\end{array}$ & Frekuensi & $\begin{array}{c}\text { Persentase } \\
(\%)\end{array}$ \\
\hline 1 & Berbeda & 0 & 0 \\
\hline 2 & $\begin{array}{l}\text { Tidak } \\
\text { Berbeda }\end{array}$ & 5 & 100 \\
\hline 3 & $\begin{array}{l}\text { Kadang- } \\
\text { kadang }\end{array}$ & 0 & 0 \\
\hline \multicolumn{2}{|c|}{ Jumlah } & 5 & 100 \\
\hline
\end{tabular}

Sumber: Hasil Kuesioner Pegawai, 2014

Berdasarkan penyajian data di atas terlihat bahwa seluruh responden menyatakan tidak ada perbedaan dalam memberikan pelayanan kesehatan kepada pasien pengguna kartu BPJS Kesehatan dengan pasien umum lainnya. Hal tersebut terlihat bahwa 5 orang $(100 \%)$ menjawab tidak berbeda. Dalam pengamatan penulis, petugas Puskesmas baik itu dokter, perawat, 
asisten apoteker atau pada bagian farmasi dan para medis lainnya, memang memberikan pelayanan yang sama terhadap semua pasien. Akan tetapi perbedaan yang terlihat pada pasien pengguna kartu BPJS kesehatan dengan pasien umum lainnya adalah pada bagian administrasi, karena pada dasarnya pasien yang berobat dengan menggunakan kartu BPJS Keseharan tidak dikenakan biaya.

\section{b. Kualitas Layanan}

Kualitas layanan menyangkut tanggapan proses layanan oleh pengguna layanan. Adapun tanggapan mengenai hal ini adalah sebagai berikut.

Tabel 2

Tanggapan Tentang Kualitas Layanan

\begin{tabular}{|c|l|c|c|}
\hline No & $\begin{array}{l}\text { Tanggapan } \\
\text { Responden }\end{array}$ & Frekuensi & $\begin{array}{c}\text { Persentase } \\
(\%)\end{array}$ \\
\hline 1 & Berkualitas & 3 & 60 \\
\hline 2 & $\begin{array}{l}\text { Kurang } \\
\text { Berkualitas }\end{array}$ & 2 & 40 \\
\hline 3 & $\begin{array}{l}\text { Tidak } \\
\text { Berkualitas }\end{array}$ & 0 & 0 \\
\hline \multicolumn{2}{|c|}{ Jumlah } & 5 & 100 \\
\hline
\end{tabular}

Sumber: Hasil Kuesioner Pegawai, 2014

Berdasarkan tabel di atas dapat diketahui bahwa ada 3 orang (60\%) menyatakan bahwa berkualitas obat yang diberikan kepada pasien pengguna kartu BPJS Kesehatan, dan ada 2 orang (40\%) yang menyatakan bahwa kurang berkualitas obat-obatan yang diberikan kepada pasien pengguna kartu BPJS Kesehatan. Hal ini bisa terjadi mungkin ada beberapa alasan yang mendasar. Menurut penulis amati selama melakukan penelitian dan riset di Puskesmas Wajo, memang obat yang ada di Puskesmas Wajo tidak semuanya merupakan obat-obat yang berkualitas. Biasanya pasien yang datang berobat kebanyakan menderita penyakit ringan, hanya diberikan obat generik saja.

\section{c. Kehandalan Pelayanan}

Kehandalan pelayanan menyangkut pengelolaan waktu layanan kepada masyarakat. Adapun tanggapn mengenai hal ini adalah sebagai berikut.

Tabel 3

Tanggapan Tentang Kehandalan Pelayanan

\begin{tabular}{|c|l|c|c|}
\hline No & $\begin{array}{l}\text { Tanggapan } \\
\text { Responden }\end{array}$ & Frekuensi & $\begin{array}{c}\text { Persentase } \\
(\%)\end{array}$ \\
\hline 1 & Sigap & 5 & 100 \\
\hline 2 & $\begin{array}{l}\text { Kurang } \\
\text { Sigap }\end{array}$ & 0 & 0 \\
\hline 3 & $\begin{array}{l}\text { Tidak } \\
\text { Sigap }\end{array}$ & 0 & 0 \\
\hline \multicolumn{2}{|c|}{ Jumlah } & 5 & 100 \\
\hline
\end{tabular}

Sumber: Hasil Kuesioner Pegawai, 2014

Berdasarkan tabel di atas, terlihat bahwa seluruh responden 5 orang (100\%) menyatakan sigap dalam memberikan pelayanan kepada pasien pengguna kartu BPJS Kesehatan. Responden menyadari bahwa kesigapan sangat diperlukan dalam proses pelayanan di Puskesmas. Karena kesigapan merupakan bukti dari profesional setiap pegawai yang ada di Puskesmas, baik itu dokter, perawat, maupun para medis lainnya.

Tabel.4

Tanggapan Tentang Kehandalan Pelayanan

\begin{tabular}{|c|l|c|c|}
\hline No & $\begin{array}{l}\text { Tanggapan } \\
\text { Responden }\end{array}$ & Frekuensi & $\begin{array}{c}\text { Persentase } \\
(\%)\end{array}$ \\
\hline 1 & Sigap & 5 & 100 \\
\hline 2 & $\begin{array}{l}\text { Kurang } \\
\text { Sigap }\end{array}$ & 0 & 0 \\
\hline 3 & $\begin{array}{l}\text { Tidak } \\
\text { Sigap }\end{array}$ & 0 & 0 \\
\hline \multicolumn{2}{|c|}{ Jumlah } & 5 & 100 \\
\hline
\end{tabular}

Sumber: Hasil Kuesioner Pegawai, 2014

Berdasarkan tabel di atas terlihat bahwa seluruh pegwai Puskesmas 
menyatakan sigap dalam menangani keluhan dari setiap pasien pengguna kartu BPJS Kesehatan. Hal tersebut terbukti dari data di atas, terdapat 5 orang (100\%) yang menjawab sigap.

Dari pengamatan penulis selama melakukan penelitian, terlihat memang dokter, perawat atau para pegawai lainnya sigap dalam menangani setiap keluhan yang ada pada pasien, dan pengguna kartu BPJS Kesehatan.

\section{d. Akses Terhadap Pelayanan}

Hal ini menyangkut intensitas pengguna layanan (masyarakat) yang kemudian diukur dengan indikator kunjungan masyarakat terhadap pelayanan. Tanggapan mengani hal ini dapat dilihat sebagai berikut.

Tabel 5

Tanggapan Tentang Akses Terhadap Pelayanan

\begin{tabular}{|c|l|c|c|}
\hline No & $\begin{array}{l}\text { Tanggapan } \\
\text { Responden }\end{array}$ & Frekuensi & $\begin{array}{c}\text { Persentase } \\
(\%)\end{array}$ \\
\hline 1 & Serin & 4 & 80 \\
\hline 2 & $\begin{array}{l}\text { Kadang- } \\
\text { kadang }\end{array}$ & 1 & 20 \\
\hline 3 & $\begin{array}{l}\text { Tidak } \\
\text { Pernah }\end{array}$ & 0 & 0 \\
\hline \multicolumn{2}{|c|}{ Jumlah } & 5 & 100 \\
\hline
\end{tabular}

Sumber: Hasil Kuesioner Pegawai, 2014

Berdasarkan tabel di atas dapat diketahui bahwa 4 orang (80\%) menyatakan bahwa sering pasien BPJS Kesehatan yang sama datang berobat ke Puskesmas Wajo. Karena biasanya pasien yang datang berobat ke Puskesmas Wajo berobat dalam sebulan bisa sampai 2-3 kali dengan penyakit yang sama. Hal tersebut bisa saja terjado karena penyakit yang diderita pasien belum sembuh, atau obat yang diberikan dokter sudah habis dan tentunya ada alasan-alasan lainnya yang membuat pasien yang sama sering datang berkunjung ke Puskesmas Wajo. Dan terlihat juga dari tabel di atas terdapat 1 orang (20\%) menyatakan kadang-kadang pasien yang sama datang berkunjung ke Puskesmas Wajo. Dan itu bisa terjadi karena kebanyakan pasien yang berobat ke Puskesmas Wajo dalam sebulan sekitar 1-2 kali.

\section{e. Prosedur Layanan}

Hal ini menyangkut mekanisme prosedur layanan yang dialami oleh pengguna layanan. Adapun tanggapan mengenai hal ini adalah sebagai berikut.

Tabel 6

Tanggapan Tentang Prosedur Layanan

\begin{tabular}{|c|l|c|c|}
\hline No & $\begin{array}{l}\text { Tanggapan } \\
\text { Responden }\end{array}$ & Frekuensi & $\begin{array}{c}\text { Persentase } \\
(\%)\end{array}$ \\
\hline 1 & Cepat & 5 & 100 \\
\hline 2 & $\begin{array}{l}\text { Kurang } \\
\text { Cepat }\end{array}$ & 0 & 0 \\
\hline 3 & $\begin{array}{l}\text { Tidak } \\
\text { Cepat }\end{array}$ & 0 & 0 \\
\hline \multicolumn{2}{|c|}{ Jumlah } & 5 & 100 \\
\hline
\end{tabular}

Sumber: Hasil Kuesioner Pegawai, 2014

Berdasarkan dari tabel di atas terlihat bahwa seluruh responden yang ada yaitu 5 orang (100\%) menyatakan bahwa pasien BPJS Kesehatan yang datang berobat ke Puskesmas Wajo cepat mengalami kesembuhan dari penyakit yang diderita oleh pasien. Hal tersebut dikarenakan pelayanan yang diberikan pegawai Puskesmas termasuk itu dokter sangat baik dan memuaskan, begitu juga kepada obat-obatan yang diberikan kepada pasien pengguna kartu BPJS Keseharan juga berkualitas.

\section{f. Fasilitas layanan}

Hal ini menyangkut ketersediaan fasilitas dalam menunjang pelayanan. Adapun tanggapan mengenai hal ini adalah sebagai berikut. 
Tabel 7

Tanggapan Fasilitas Pelayanan

\begin{tabular}{|c|c|c|c|}
\hline No & $\begin{array}{l}\text { Tanggapan } \\
\text { Responden }\end{array}$ & Frekuensi & $\begin{array}{c}\text { Persentase } \\
(\%)\end{array}$ \\
\hline 1 & Memenuhi & 2 & 40 \\
\hline 2 & $\begin{array}{l}\text { Kurang } \\
\text { Memenuhi }\end{array}$ & 3 & 60 \\
\hline 3 & $\begin{array}{l}\text { Tidak } \\
\text { Memenuhi }\end{array}$ & 0 & 0 \\
\hline & Jumlah & 5 & 100 \\
\hline
\end{tabular}

Sumber: Hasil Kuesioner Pegawai, 2014

Berdasarkan data di atas terlihat bahwa terdapat 3 orang (60\%) yang menyatakan persediaan obat-obatan yang diberikan oleh Puskesmas Wajo masih kurang memenuhi bagi kebutuhan pasien. Hal ini terlihat dari cepat habisnya persediaan obat-obatan yang ada di Puskesmas Wajo. Dan 2 orang responden (40\%) yang menyatakan persediaan obat-obatan yang ada di Puskesmas Wajo sudah memenuhi kebutuhan pasien pengguna BPJS Kesehatan.

\section{2) Kondisi Sumber Daya Manusia (Aparat).}

Dalam menciptakan pelayanan public yang berkualitas, selain harus didukung oleh system pelayanan yang baik juga harus didukung pula oleh sumber daya dalam hal ini penyedia layanan atau aparat. Adapun gambaran tentang kondisi sumberdaya manusia tersebut yang didapati dari tanggapan responden (pengguna layanan) adalah sebagai berikut :

\section{a. Kedisiplinan}

Dengan adanya kedispilinan yang baik dari aparatur, tentu akan mendukung terciptanya pelayanan yang berkualitas. Berikut tanggapan mengenai kedispilinan aparat.
Tabel 8

Tanggapan Terhadap Kedisplinan

Aparat

\begin{tabular}{|c|l|c|c|}
\hline No & $\begin{array}{l}\text { Tanggapan } \\
\text { Responden }\end{array}$ & Frekuensi & $\begin{array}{c}\text { Persentase } \\
(\%)\end{array}$ \\
\hline 1 & Disiplin & 47 & 78,33 \\
\hline 2 & $\begin{array}{l}\text { Kurang } \\
\text { Disiplin }\end{array}$ & 12 & 20 \\
\hline 3 & $\begin{array}{l}\text { Tidak } \\
\text { Disiplin }\end{array}$ & 1 & 1,67 \\
\hline \multicolumn{2}{|c|}{ Jumlah } & 60 & 100 \\
\hline
\end{tabular}

Sumber: Hasil Kuesioner Pasien, 2014

Berdasarkan tabel di atas, dapat diketahui bahwa yang menyatakan dokter sudah disiplin hadir di Puskesmas Wajo ada sebanyak 47 responden (78,33\%) dan yang menyatakan dokter kurang disiplin sebanyak 12 orang (20\%), dan yang menyatakan kehadiran dokter Puskesmas Wajo tidak disiplin hanya 1 responden $(1,67 \%)$.

Dari tanggapan responden di atas, dapat disimpulkan bahwa tidak semua responden pasien BPJS Kesehatan puas dengan pelayanan yang ada di Puskesmas Wajo. Hal tersebut terlihat dari masih ada beberapa responden yang menyatakan kehadiran dokter Puskesmas Wajo masih kurang disiplin.

Tentunya dari perbedaan pernyataan responden pasien pengguna kartu BPJS Kesehatan tentang kedisiplinan kehadiran dokter, pastinya dokter Puskesmas Wajo juga punya alasan-alasan lain mengenai kedisiplinan kehadirannya sebagai pegawai Puskesmas Wajo.

\section{b. Kehandalan Aparatur}

Hal ini menyangkut kinerja aparatur dalam melaksanakan pelayanan kepada pengguna layanan, ini mendukung kemudahan dalam pelayanan. Tanggapan mengenai hal ini ; 
Tabel 9

Tanggapan Terhadap Kemudahan Pelayanan

\begin{tabular}{|c|l|c|c|}
\hline No & $\begin{array}{l}\text { Tanggapan } \\
\text { Responden }\end{array}$ & Frekuensi & $\begin{array}{c}\text { Persentase } \\
(\%)\end{array}$ \\
\hline 1 & Mudah & 55 & 91,67 \\
\hline 2 & $\begin{array}{l}\text { Kurang } \\
\text { Mudah }\end{array}$ & 5 & 8,33 \\
\hline 3 & $\begin{array}{l}\text { Tidak } \\
\text { Mudah }\end{array}$ & 0 & 0 \\
\hline \multicolumn{2}{|c|}{ Jumlah } & 60 & 100 \\
\hline
\end{tabular}

Sumber: Hasil Kuesioner Pasien 2014

Berdasarkan tabel di atas diketahui terdapat hampir seluruh responden yaitu sebanyak 55 orang $(91,67 \%)$ yang menyatakan bahwa pelayanan yang diberikan kepada pasien BPJS Kesehatan memudahkan responden dalam berobat di Puskesmas Wajo.

Hal ini terbukti dari pelayanan awal yaitu lolet pendaftaran berobat, lalu ke ruang tunggu, kemudian masuk ke ruang pemeriksaan, hingga menuju ke pengambilan obat di apotek, dan semuanya memberikan kemudahan.

Dari data di atas, di dapat juga 5 orang responden $(8,33 \%)$ yang menyatakan masih kurang mudah pelayanan yang diberikan ketika berobat di Puskesmas Wajo. Ini mungkin terjadi, banyaknya pasien BPJS Kesehatan yang datang di hari-hari pertama seperti hari Senin. Tentunya pada hari Senin pasien harus mengantri. Makanya terlihat seperti pelayanan yang diberikan kurang mudah.

Tabel 10

Tanggapan Tentang Proses Pelayanan

\begin{tabular}{|c|l|c|c|}
\hline No & $\begin{array}{c}\text { Tanggapan } \\
\text { Responden }\end{array}$ & Frekuensi & $\begin{array}{c}\text { Persentase } \\
(\%)\end{array}$ \\
\hline 1 & Lancar & 54 & 90 \\
\hline 2 & Berbelit-belit & 5 & 8,33 \\
\hline 3 & $\begin{array}{l}\text { Kurang } \\
\text { Lancar }\end{array}$ & 1 & 1,67 \\
\hline \multicolumn{2}{|c|}{ Jumlah } & 60 & 100 \\
\hline
\end{tabular}

Sumber: Hasil Kuesioner Pasien 2014

Dari data di atas, terlihat bahwa ada 54 orang responden (90\%) yang menyatakan bahwa proses pelayanan yang diberikan tidak berbelit-belit atau lancar. Alasannya adalah pasien BPJS sudah banyak mengetahui struktur dari proses pelayanan puskesmas, seperti yang sudah dijelaskan pada tabel 39, datang langsung ke loket pendaftaran, lalu menuju ruang tunggu dan kemudian masuk ke ruang pemeriksaan yaitu poli umum dan setelah itu langsung ke tempat pengambilan obat yaitu apotek yang ada di Puskesmas Wajo.

Terlihat juga dari data di atas, ada 5 orang responden (8,33\%) yang menyatakan proses pelayanan yang ada di Puskesmas Wajo masih berbelit-belit. Namun juga ada 1 orang responden $(1,67 \%)$ yang menyatakan proses pelayanannya kurang lancar. Menurut pengamatan penulis, hal ini terjadi karena sering beberapa kali file pasien BPJS yang ada di bagiankartu tidak ketemu, atau tercecer, sehingga proses pelayanannya pun menjadi kurang lancar. Karena pasien BPJS ingin vepat berobat di Puskesmas, tetapi file berobat pasientidak ketemu maka hal ini menjadi penyebab kurang lancarnya proses pelayanan.

\section{PENUTUP}

\section{Kesimpulan}

Berdasarkan hasil penelitian yang telah diuraikan pada bab-bab sebelumnya, maka pada bab ini penulis mengemukakan beberapa kesimpulan sebagai berikut:

1. Puskesmas Wajo adalah puskesmas yang memberikan pelayanan kesehatan kepada masyarakat, salah satunya seperti kepada peserta BPJS Kesehatan atau pasien pengguna 


$\begin{array}{lcr}\text { kartu BPJS } & \text { Kesehatan } & \text { berupa } \\ \text { pengobatan } & \text { gratis } & \text { dengan } \\ \text { menunjukkan } & \text { kartu } & \text { BPJS } \\ \text { Kesehatan. } & & \end{array}$

2. Pelayanan yang diberikan oleh pihak Puskesmas Wajo terhadap pasien khususnya pengguna kartu BPJS Kesehatan telah terlaksana dengan baik dan sudah berjalan dengan lancar. Hal ini terbukti dari respon yang baik diberikan pasien BPJS Kesehatan dalam menanggapi semua pelayanan yang ada di Puskesmas Wajo baik dari kualitas, kehandalan, kesigapan, fasilitas dan lain-lain.

3. Dari hasil penelitian dapat disimpulkan bahwa pelayanan kesehatan di Puskesmas Wajo dikatan sudah efektif karena pelayanan yang diberikan dapat meningkatkan kesehatan pada pasien BPJS Kesehatan.

\section{Saran}

Berdasarkan kesimpulan di atas, maka penulis mencoba memberikan masukan-masukan atau saran yang ditujukan untuk mengoptimalkan pelayanan kesehatan pasien pengguna kartu BPJS Kesehatan di Puskesmas Wajo, antara lain:

1. Pertahankan terus sikap ramah dan senyum kepada pasien BPJS Kesehatan agar terjadi hubungan yang baik dan komunikasi yang baik sehingga pelayanan yang diberikan dapat berjalan secara efektif.

2. Diharapkan obat-obatan yang ada di Puskesmas Wajo lebih ditingkatkan lagi kualitasnya.

3. Fasilitas yang ada seperti timbangan, bangku, komputer, kamar mandi/WC dapat diperbaiki, diperbaharui dan ditambah guna memperlancar pelayanan bagi pasien BPJS Kesehatan khususnya yang datang berobat ke Puskesmas Wajo. 


\section{E. DAFTAR PUSTAKA}

Anwar, A. 2009. Program Menjaga Mutu Pelayanan Kesehatan. Jakarta: Yayasan Ikatan Dokter Indonesia

Boediono. 2010. Pelayanan Prima Perpajakan. Jakarta: Rineka Cipta

Cambel, JP. 2008. Riset Dalam Efektivitas Organisasi. Terjemahan Sahat Simamora. Jakarta: Erlangga

Hadayaningrat, Soewarno. 2008. Pengantar Ilmu Administrasi Manajemen. Jakarta: Gunung Agung

Hidayat. 2010. Teori Efektivitas Dalam Kinerja Karyawan. Yogyakarta: Gajah Mada University

Juanta. 2008. Ekonomi Kesehatan Untuk Negara-Negara Sedang Berkembang. Jakarta: Dian Rakyat

Kasim, Azhar. 2010. Pengukuran Efektivitas Dalam Organisasi. Jakarta: Universitas Indonesia

Kurniawan, Agung. 2009. Transformasi Pelayanan Publik. Yogyakarta: Pembaruan

Martani dan Lubis. 2009. Efektivitas Organisasi. Jakarta: Bumi Aksara

Napitupulu, Paimin. 2007. Pelayanan Publik dan Costumer Statisfiction. Bandung: Alumni

Nawawi, Hadari. 2009. Metode Penelitian Bidang Sosial. Yogyakarta: Gadjah Mada University Press
Riawan, Tjandra. 2009. Peningkatan Kapasitas Pemda Dalam Pelayanan Publik. Yogyakarta: Pembaruan

Ridwan, Juniarso. 2009. Hukum Administrasi Negara Dan Kebijakan Pelayanan Publik. Bandung: Nuansa

Siagian, S.P. 2008. Penelitian Untuk Mengevaluasi Efektivitas Program-Prgram Kemasyarakatan. Surabaya: Usaha Nasional

Sinambela, LP. 2008. Reformasi Pelayanan Pubvlik, Teori, Kebijakan dan Implementasi. Jakarta: Bumi Aksara

Steers. M Richard. 2008. Efektivitas Organisasi. Jakarta: Erlangga

Sugiyono 2008. Metode Penelitian Survey. Jakarta: LP3ES

Waluyo. 2007. Manajemen Publik, Konsep, Aplikasi dan Implementasinya Dalam Pelaksanaan Otonomo Daerah. Bandung: Mandar Maju 